\title{
A technical guide to develop a statistically valid fish-based index in compliance with the water framework directive: an evaluation for Turkish freshwaters
}

\author{
Mehmet Borga Ergönül • Jan Breine • \\ Erika Van den Bergh
}

Received: 12 June 2018/Accepted: 2 November 2018/Published online: 10 November 2018

(C) The Author(s) 2018

\begin{abstract}
Fish are considered as reliable indicators of environmental quality and during the last decades several fish-based indices have been developed to assess the ecological status of water bodies in compliance with the water framework directive. The high number of fish species with a high degree of endemism, lack of knowledge on ecological requirements of certain fish species, absence of a complete dataset for reference conditions, and great variation among freshwater types complicate the development of fish-based indices for Turkish freshwaters. However, this is still possible using statistical approaches. This paper presents a practical guide which is mainly based on the recent approaches that have frequently been used in other countries worldwide. Data collection, metric selection and scoring, ecological quality ratio (EQR) calculation and validation steps are described and discussed with respect to the limitations and available data for Turkish freshwaters. The guide documented here, with minor adjustments, has a potential to be adopted as a fish-based assessment approach for the ecological status in freshwaters in Turkey and adjacent countries.
\end{abstract}

Keywords Ecological quality ratio $\cdot$ Fish-based index $\cdot$ Water framework directive $\cdot$ Modeling $\cdot$ Index of biotic integrity

\section{Introduction}

During the last decades, modification of natural flow regime, effluent discharge, excessive use of pesticides and fertilizers, deterioration of natural floodplain and river beds led to a series of alterations in the species composition and abundance of aquatic living organisms, and the physical and chemical features of the water bodies (Meybeck et al. 1996; Jekel 2005; Gallardo et al. 2016). Assessment of the ecological status of these ecosystems is important for managers and policy makers to design appropriate regulations and management strategies (Boulton 1999). Consequently, the European Union published the water framework directive (WFD) on 22 December 2000 which was entered into force on the same day. The main objective of WFD is to achieve

\footnotetext{
M. B. Ergönül ( $\bowtie)$

Department of Biology, Faculty of Science, Ankara University, Tandoğan, 06100 Ankara, Turkey

e-mail: ergonul@gmail.com

J. Breine

Instituut voor Natuur-en Bosonderzoek, Dwersbos 28, Linkebeek, 1630 Brussels, Belgium

E. Van den Bergh

Instituut voor Natuur-en Bosonderzoek, Havenlaan 88 bus 73, 1000 Brussels, Belgium
} 
and maintain good ecological and chemical status in all water bodies to protect human health, water supply, natural ecosystems and biodiversity (EU WFD 2000).

Conventional methods based solely on chemical and/or physical water quality parameters are not considered as reliable approaches to evaluate the ecological status for surface waters (Meybeck et al. 1996; Hunting et al. 2017). Thus, WFD imposes the use of biological quality elements, including fish, to assess the ecological status in water bodies. In general, fish have representatives in a broad range of trophic levels, and a relatively high mobility and long life span, which makes them reliable indicators on a large spatial and long time scale (Karr 1981; Moore et al. 1997; Pont et al. 2007; Noble et al. 2007). Several studies emphasize the merits of fish data for environmental quality assessment (Fausch et al. 1990; Moore et al. 1997; Whitfield and Elliott 2002; Saravanan et al. 2003) and several statistical approaches have been developed to appraise the ecological status of water bodies by using fish-based indices (Fame Consortium 2004; Pont et al. 2007; EFI + Consortium 2009). Fish-based indices incorporating fish community data (species composition, abundance, biomass, etc.) and abiotic variables ( $\mathrm{pH}$, oxygen, altitude, slope, etc.) (Clavel et al. 2013; Aazami et al. 2015) are robust and powerful tools to reveal the effects of human activities (construction of dams, water abstraction, habitat fragmentation, etc.) on aquatic habitats (Lyons 2012; Sundermann et al. 2013; Mostafavi et al. 2015; Schnier et al. 2016).

The first fish-based index, the Index of Biotic Integrity (IBI), was developed for Midwestern USA streams (Karr 1981) and has been modified to be used all over the world. As such, several fish-based indices have been developed for lakes and rivers in America (Cunico et al. 2011), Canada (Stevens and Council 2008), NewZealand (Joy and Death 2004), Africa (Hugueny et al. 1996) and Europe (Noble et al. 2007; Breine et al. 2010; 2015). Fish-based indices are available only from Pakistan (Qadir and Malik 2009), China (Wu et al. 2014), Taiwan (Hu et al. 2007) and Iran (Mostafavi et al. 2015) in Asia. Only one report on a fish-based index has been published recently for Akarçay and Küçük Menderes Basins in Turkey (Yerli et al. 2016). However, fishbased indices developed for specific regions and habitats with particular fish assemblages (e.g., EFI + for European freshwater fishes) cannot be used elsewhere without any adaptations and adjustments (Karr and Chu 1999; Pont et al. 2007; Wang et al. 2007). Thus, there is an increasing need for the development of fish-based national ecological evaluation tools to assist policy makers in Turkey.

Developing fish-based national ecological assessment tools for Turkish freshwaters has some drawbacks: the number of species is quite high with a considerable degree of endemism (Kuru et al. 2014), typology shows great variation among ecoregions and there are limited data on the distribution and species specific ecological requirements of certain fish (especially endemic fish) (Yerli et al. 2016). A total of 1814 riverine and 656 lacustrine freshwater habitats have been defined in 25 different catchment basins in Turkey (RBPAP 2013). These riverine and lacustrine habitats are classified into 56 and 23 different types, respectively, which is another challenging factor. The absence of a complete dataset on the reference conditions for riverine and lacustrine habitats also complicates the development of the indices. Fortunately, it is still possible to develop a valid fish-based index using appropriate statistical approaches. In this study, we present a statistical protocol for a fish-based index development process including data collection, metric selection and scoring, Ecological Quality Ratio (EQR) calculation and validation steps with respect to the limitations and drawbacks summarized above for Turkish freshwaters. Monitoring the biological quality elements without reliable and precise evaluation approaches is a waste of time and money (Irvine 2004). Thus, to be useful for the managers and policy makers, these indices must meet at least the following criteria: (1) they must be sensitive to human disturbance, (2) they should measure the variation in community patterns (i.e., species composition, abundance, biomass, etc.) and disturbance at a scale that is useful for management and (3) they should include interpretable metrics (Schoolmaster et al. 2013). The protocol explained here has the potential to be used in the development of a fish-based assessment approach for the freshwaters in Turkey and adjacent countries.

\section{Index development}

The development of a fish-based index is a complex procedure consisting of the following steps: data collection (fish sampling and abiotic data recording), selection of the candidate metrics and final metrics, scoring of the selected metrics, EQR calculation and determination of thresholds for integrity classes and 


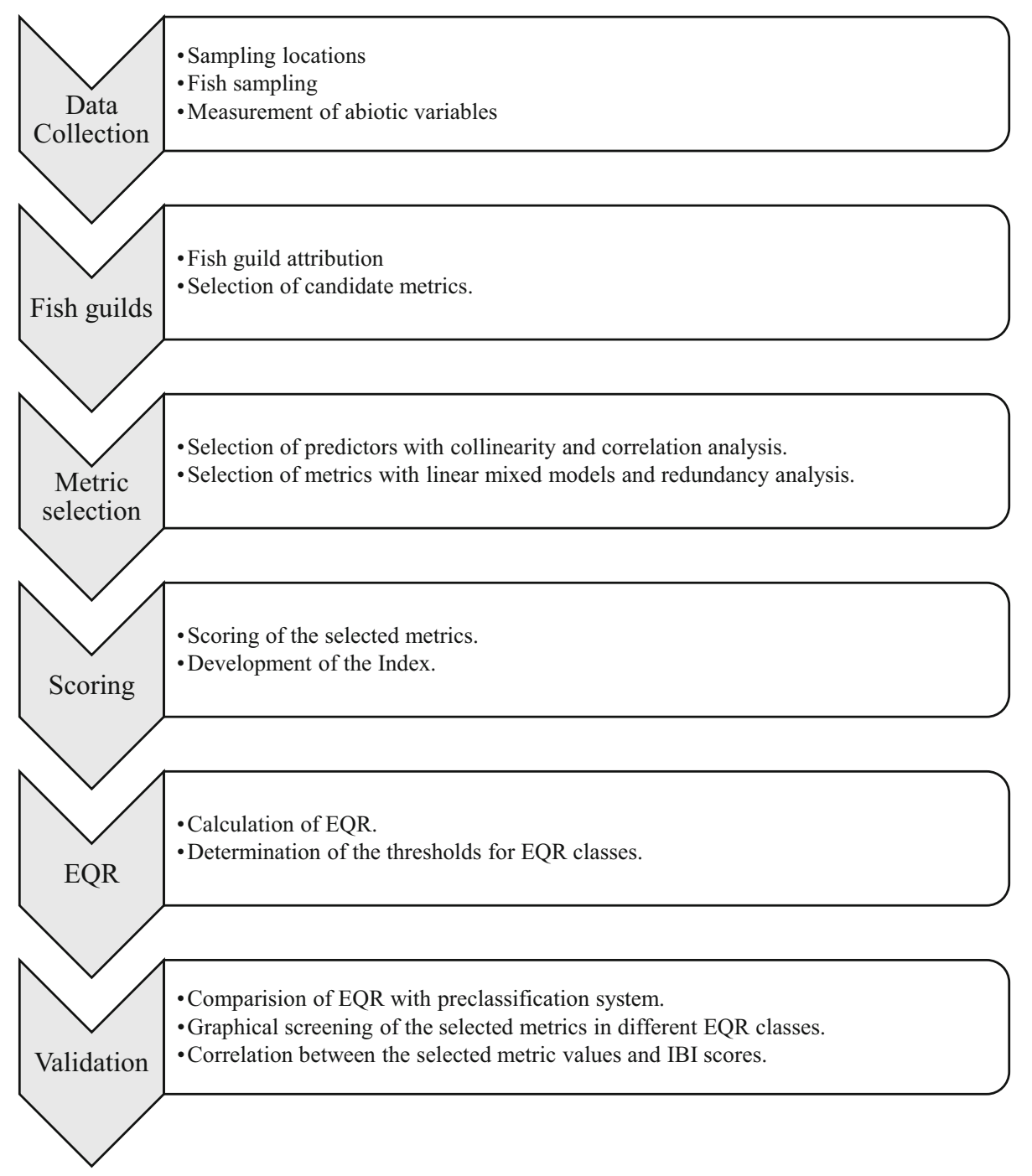

Fig. 1 Flowchart of a fish-based index development

validation. A brief workflow for the index development is given in Fig. 1. Each of these steps is summarized below.

Data collection

To develop a fish-based IBI for rivers, lakes or reservoirs, biotic and abiotic data should be collected from a wide range of sampling locations ranging from the least disturbed (i.e., having no or minor disturbances related to anthropogenic activities) to the most impacted locations, including a gradient of sites regarding human impacts (Gernes and Helgen 2002; Hering et al. 2006). The least impacted sampling locations for the different types can be selected utilizing pressure criteria (Anonymous 2003). Furthermore, the sampling locations selected on rivers should also represent an upstream-dow0010841nstream gradient along the whole river.

\section{Fish sampling}

For the assessment of ecological status in water bodies, the WFD proposes to use standardized fish sampling protocols as described by the European Committee for Standardization (CEN 2003a; CEN 2003b) with minor 
adjustments regarding the characteristics of water bodies and climatic conditions in the watershed. In general, electrofishing equipment and multi-mesh gill nets are recommended in rivers and lakes, respectively. The type and features of the electrofishing equipment chosen and the number of staff depend on the current velocity, width and depth. Backpack electrofishing devices are useful for wadable rivers. However, a boat may be required in large rivers. In each sampling location, electrofishing should include all habitats such as river banks, downed trees, and backwaters. Although the WFD has no recommendations for sampling season, late summer or early autumn seems to be suitable for Turkish rivers to avoid high water current velocity in spring. For lakes, the use of benthic and/or pelagic multi-mesh gill nets is recommended depending on the target fish and/or depth. The fishing effort (i.e., number of gill nets to be used) depends on the lake surface area, depth and habitat diversity. If available, a bathymetric map can be used to decide where to cast nets. Data collected by different sampling methods should not be combined or mixed to reduce the bias related to any single protocol (U.S. EPA 2002).

Fish caught in the field should be identified to the species level and the length (total length or standard length) and weight of each individual should be recorded. A few individuals can be retained and fixed in $10 \%$ formaldehyde if in situ identification is not possible. Photographs of live or freshly fixed specimens taken according to the tutorial described by Freyhof (2018) are useful for identification. To intercalibrate the fishing efforts, data should be transformed to catch per unit effort (number/biomass per $\mathrm{m}^{2}$ ).

\section{Abiotic variables}

The quality and reliability of abiotic data play a key role for classification of sampling sites. Appropriate sampling equipment should be used and relevant sampling standards (e.g., ISO 5667-6 (2014) for rivers and ISO 5667-4 (2016) for lakes) should be followed. The sampling staff should be trained and experienced in such procedures. Further details can be found in the relevant standards (ISO Standard Series 5667; Part 1 (2010), 3 (2012), (2016) 4 and 6 (2014)).

Abiotic variables should include a series of both physico-chemical and hydromorphological parameters. Spot samples are suitable for rivers in most circumstances. In stratified lakes, samples from different depths may be needed to achieve a better interpretation. Additionally, monitoring the level of pollutants in samples from sediment and biota are useful to assess long-term human impacts.

The general objectives of this data collection are to rank the sampling sites according to a gradient of human disturbances in the preclassification phase and to understand why biological communities are damaged during the IBI interpretation phase (U.S. EPA 2002). Any information on the human activities which may affect fish communities and physical environment is crucial for the preclassification of sampling locations. A wide range of domestic, urban, agricultural, and industrial sources of pressures can be used for the preclassification. Pressure criteria can be based on waste water discharge, organic and inorganic pollution loads, land use, water withdrawal from lakes, rivers or groundwater, alteration of natural flow regime due to the presence of dams and regulators, channelization, presence of aquaculture facilities, deforestation, deterioration of riparian vegetation and flood plain, disturbance of river beds due to sand pits, etc. within a buffer area (e.g., $500 \mathrm{~m}$ ) around the sampling point. A part of these data (e.g., presence of dams, deforestation, land use) can be extracted using GIS (Geographic Information Systems). Land use maps and low altitude aerial photographs taken from each sampling location are also useful.

The information on the human pressures including point and non-point sources of total nitrogen and phosphorus loads, organic and inorganic pollution loads is available via the technical reports of River Basin Protection Action Plans (RBPAP) and Sensitive Areas Project (SAP) for 25 different river basins in Turkey (RBPAP 2013; SAP 2016) and can assist in scoring the pressures to aid the preclassification of sampling locations. The categorical pressure variables (i.e., present or absent) are scored as 1 and 0 , respectively. Other pressure variables which are counts or proportions (e.g., mean nutrient loads) are ranked and scored between 1 and 5: 1 indicating the best conditions and 5 the most unfavorable conditions among sampling locations. Thus, the sum of these scores can be used for preclassification; lowest corresponding to the least impaired and highest to the most impacted. A similar approach is described by Gernes and Helgen (2002). The preclassification system based on pressures caused by human activities is useful, particularly if the reference conditions are not known. 
Selection of the candidate metrics

One of the most important steps for developing a statistically valid fish-based index is the metric selection using appropriate statistical tools. A metric is a variable assessing an ecological attribute of a fish community that is sensitive to human activity and reacts unambiguously to the variation of this human activity (Karr and Chu 1999).

Fish species utilizing and/or requiring similar resources (food, habitat, water quality, etc.) for feeding, reproduction and growth can be grouped into same guilds (Bain et al. 1988; Noble et al. 2007). Life history, residency status and tolerance to environmental disturbances of fish can also be used for guild attribution. The guild attribution of fish species should be the same among sampling locations and/or researchers (Schmutz et al. 2007). Candidate metrics include species richness indices, number of species, number and relative percentages of individuals and biomass of fish in each guild. Novel metrics which are potentially useful can be tested (Schmutz et al. 2007). A list of candidate metrics frequently used for fish-based indices and their predicted response to the environmental disturbances (see Sect. 2.1.3) (Fame Consortium 2004; Noble et al. 2007) is given in Table 1.

Selection of the final metrics

To fulfill the requirements of a statistically valid fish index, candidate metrics should be tested for their responsiveness to environmental disturbances. Selected metrics should cover the different ecological functions (Table 1) and redundant metrics should be avoided. Redundancy can be analyzed using correlation test. Different thresholds for redundancy are found in the literature; e.g., Hering et al. (2006) mention $c>0.8$ but in other studies lower correlations ranging between 0.75 and 0.7 have also been accepted (Fame Consortium 2004; Breine et al. 2010).

Different selection approaches are available. Graphical screening of box-plots showing the metric values as a function of the preclassified sites can be used as a visual method for preliminary selection. Principal component analysis (PCA) and canonical correspondence analyses (CCA) were used frequently to monitor responsiveness (see review, ter Braak and Verdonschot 1995). Multimetric regression models including linear mixed effect models have been favored to select responding metrics in the recent fish-based index studies (Tableau et al. 2013; Breine et al. 2015; Smolinski and Calkiewicz 2015).

Whole data, including predictors (abiotic and pressure variables) and metrics (count, percentage), should be transformed to meet the specifications of linear models (Breine et al. 2015). The predictors included in modeling should be selected on the basis of redundancy (collinearity and correlation) tests to avoid circular thinking. Collinearity and correlation are tested with variance influence factor (VIF) and bivariate Pearson correlation tests, respectively. The full models should include initially all non-redundant predictors and a stepwise backward selection is applied until only statistically significant parameters remain.

The goodness-of-fit for each model can be defined by calculating the marginal and conditional $R^{2}$ values (Nakagawa and Schielzeth 2013). The metrics are selected on the basis of the significance of their response to predictors with a conditional $R^{2}$ value $>35 \%$. An example for the full model is given below:

model $<\operatorname{lmer}($ Metric $\sim$ predictor $-a+$ predictor $-b+$ predictor $-c+$ predictor $-d+$ predictor $-e$ )

Modeling of the fish data can be done using the statistical package program R (R Development Core Team 2012). To run linear modeling, the packages "ImerTest" and "Ime4" should be installed. The "MuMIn" package should be installed to calculate conditional $R^{2}$ values. Other packages are also available for same analyses. The excel data saved as.csv or.txt extension can be read and imported to R. Other statistical programs with different packages (e.g., SAS) can also be used. Since R is an open source program, it is more likely to get help from the scientific community. 
Table 1 A list of candidate metrics frequently used in fish-based indices and their predicted response (up or down arrows) to increasing disturbances

\begin{tabular}{|c|c|c|c|c|}
\hline $\begin{array}{l}\text { Ecological } \\
\text { function }\end{array}$ & Guilds and potential metrics & Explanation & Response & References \\
\hline \multirow{5}{*}{$\begin{array}{l}\text { Species } \\
\text { richness } \\
\text { and } \\
\text { composition }\end{array}$} & Shannon-Wiener & Diversity index & $\downarrow$ & $\begin{array}{l}\text { Stirne et al. } \\
\text { (1971) }\end{array}$ \\
\hline & Pilou-Evenness Index & & $\downarrow$ & $\begin{array}{l}\text { Bellan- } \\
\text { Santini } \\
(1980)\end{array}$ \\
\hline & Dominance Simpson's Index & & $\downarrow$ & $\begin{array}{r}\text { Simpson } \\
(1949)\end{array}$ \\
\hline & Camargo Index & & $\downarrow$ & $\begin{array}{r}\text { Camargo } \\
(1992)\end{array}$ \\
\hline & Number of species & Number of species caught & $\downarrow$ & $\begin{array}{l}\text { Breine et al. } \\
\quad(2004)\end{array}$ \\
\hline \multirow[t]{3}{*}{$\begin{array}{l}\text { Condition and } \\
\text { abundance }\end{array}$} & Number of individuals & Expressed as numbers $/ \mathrm{m}^{2}$ & $\downarrow \uparrow$ & $\begin{array}{l}\text { Breine et al. } \\
\quad(2004)\end{array}$ \\
\hline & Biomass & Expressed as $\mathrm{g} / \mathrm{m}^{2}$ & $\downarrow \uparrow$ & $\begin{array}{l}\text { Breine et al. } \\
\quad(2004)\end{array}$ \\
\hline & Age structure & Presence of different length classes & $\downarrow$ & $\begin{array}{l}\text { Breine et al. } \\
\text { (2004) }\end{array}$ \\
\hline \multirow[t]{4}{*}{ Habitat } & Benthic & Bottom dwelling species & $\downarrow$ & $\begin{array}{l}\text { Hughes et al. } \\
\quad(2002)\end{array}$ \\
\hline & Rheophilic & Species preferring flowing water & $\downarrow$ & $\begin{array}{l}\text { Breine et al. } \\
\quad(2004)\end{array}$ \\
\hline & Eurytopic & $\begin{array}{l}\text { Generalistic fish that are tolerant to a wide range } \\
\text { of conditions and are found in a broad range of } \\
\text { habitats }\end{array}$ & $\uparrow$ & $\begin{array}{l}\text { Pont et al. } \\
\text { (2006) }\end{array}$ \\
\hline & Limnophilic & Fish preferring stagnant water & $\uparrow$ & $\begin{array}{l}\text { Pont et al. } \\
\text { (2006) }\end{array}$ \\
\hline \multirow[t]{3}{*}{$\begin{array}{l}\text { Residency } \\
\text { status }\end{array}$} & Native & $\begin{array}{l}\text { Species naturally occurring and self-sustaining } \\
\text { population }\end{array}$ & $\downarrow$ & $\begin{array}{l}\text { Schinegger } \\
\text { et al. } \\
\text { (2013) }\end{array}$ \\
\hline & Invasive & $\begin{array}{l}\text { Alien species having a negative effect on native } \\
\text { species }\end{array}$ & $\uparrow$ & $\begin{array}{l}\text { Lodge } \\
\quad(1993)\end{array}$ \\
\hline & Exotic & Alien species & $\uparrow$ & $\begin{array}{l}\text { Schinegger } \\
\text { et al. } \\
\text { (2013) }\end{array}$ \\
\hline \multirow[t]{4}{*}{$\begin{array}{l}\text { Tolerance/ } \\
\text { resistance }\end{array}$} & Tolerant to oxygen deficiency & $\begin{array}{l}\text { Fish species that can withstand periods of low } \\
\text { oxygen concentrations }\end{array}$ & $\uparrow$ & $\begin{array}{l}\text { Belpaire } \\
\text { et al. } \\
\text { (2000) }\end{array}$ \\
\hline & Intolerant to oxygen deficiency & $\begin{array}{l}\text { Fish species that always need high oxygen } \\
\text { concentrations }(>6 \mathrm{mg} / \mathrm{l})\end{array}$ & $\downarrow$ & $\begin{array}{l}\text { Didier } \\
\quad(1997)\end{array}$ \\
\hline & Species that need shelter & $\begin{array}{l}\text { Habitat should be diverse (pools and riffles, } \\
\text { debris, etc.) }\end{array}$ & $\downarrow$ & $\begin{array}{l}\text { Belpaire } \\
\text { et al. } \\
\text { (2000) }\end{array}$ \\
\hline & Species that are habitat sensitive & $\begin{array}{l}\text { Sensitive to channelisation, bank protection, } \\
\text { dredging, etc. }\end{array}$ & $\downarrow$ & $\begin{array}{l}\text { Mostafavi } \\
\text { et al. } \\
\text { (2015) }\end{array}$ \\
\hline
\end{tabular}


Table 1 continued

\begin{tabular}{|c|c|c|c|c|}
\hline $\begin{array}{l}\text { Ecological } \\
\text { function }\end{array}$ & Guilds and potential metrics & Explanation & Response & References \\
\hline \multirow[t]{9}{*}{ Diet } & Omnivorous & $\begin{array}{l}\text { Ingest both plant and animal material by feeding } \\
\text { mainly on macrophytes, periphyton, epifauna } \\
\text { and filamentous algae }\end{array}$ & $\uparrow$ & $\begin{array}{l}\text { Pont et al. } \\
\text { (2006) }\end{array}$ \\
\hline & Piscivores & $\begin{array}{l}\text { Feed mainly on fish but may include large } \\
\text { nektonic invertebrates }\end{array}$ & $\downarrow$ & $\begin{array}{l}\text { Pont et al. } \\
\quad(2006)\end{array}$ \\
\hline & Planktivores & $\begin{array}{l}\text { Feed predominantly on zooplankton and } \\
\text { occasionally on phytoplankton in the water } \\
\text { column, mainly by filter feeding. }\end{array}$ & $\downarrow$ & Hart (1992) \\
\hline & $\begin{array}{r}\text { Hyperbenthivores/ } \\
\text { Zooplanktivores }\end{array}$ & $\begin{array}{l}\text { Feed just over the bottom, predominantly either } \\
\text { on smaller mobile invertebrates living over the } \\
\text { bottom and zooplankton }\end{array}$ & $\downarrow$ & $\begin{array}{l}\text { Pont et al. } \\
\text { (2006) }\end{array}$ \\
\hline & Hyperbenthivores/Pisciviores & $\begin{array}{l}\text { Feed just over the bottom, predominantly either } \\
\text { on larger mobile invertebrates living over the } \\
\text { bottom and fish }\end{array}$ & $\downarrow$ & $\begin{array}{l}\text { Pont et al. } \\
\quad(2006)\end{array}$ \\
\hline & Detrivores & $\begin{array}{l}\text { Feed on all the small organisms in or on the } \\
\text { surface layer of the substratum and associated } \\
\text { organic matter }\end{array}$ & $\uparrow$ & $\begin{array}{l}\text { Khali and } \\
\text { Kochzius } \\
(2002)\end{array}$ \\
\hline & Microbenthivores & $\begin{array}{l}\text { Feed mainly on benthic, epibenthic and } \\
\text { hyperbenthic fauna, with prey size }<1 \mathrm{~cm}\end{array}$ & $\downarrow$ & $\begin{array}{l}\text { Gabriels } \\
\text { et al. } \\
\text { (2010) }\end{array}$ \\
\hline & Macrobenthivores & $\begin{array}{l}\text { Feed mainly on benthic, epibenthic and } \\
\text { hyperbenthic fauna, with prey size }>1 \mathrm{~cm}\end{array}$ & $\downarrow$ & $\begin{array}{l}\text { Gabriels } \\
\text { et al. } \\
\text { (2010) }\end{array}$ \\
\hline & Herbivores & $\begin{array}{l}\text { Graze predominantly on living macroalgal and } \\
\text { macrophyte material }\end{array}$ & $\downarrow \uparrow$ & $\begin{array}{l}\text { Pont et al. } \\
\text { (2006) }\end{array}$ \\
\hline \multirow[t]{7}{*}{$\begin{array}{l}\text { Reproductive } \\
\text { mode }\end{array}$} & Lithophils & $\begin{array}{l}\text { Spawning over gravel without preparing a nest or } \\
\text { parental care }\end{array}$ & $\downarrow$ & $\begin{array}{l}\text { Oberdorff } \\
\text { and } \\
\text { Hughes } \\
\text { (1992). }\end{array}$ \\
\hline & Phytophils & Fish needing plants to deposit adhesive eggs & $\downarrow \uparrow$ & $\begin{array}{l}\text { Pont et al. } \\
\text { (2006) }\end{array}$ \\
\hline & Ostracophils & Shell dwellers using empty shells for breeding & $\downarrow$ & $\begin{array}{l}\text { Didier } \\
\quad(1997)\end{array}$ \\
\hline & Phytolithophils & $\begin{array}{l}\text { Adhesive eggs released over plants } \\
\text { (nonobligatory) }\end{array}$ & $\downarrow \uparrow$ & $\begin{array}{l}\text { Growns } \\
\quad(2004)\end{array}$ \\
\hline & Pelagophils & Free-floating eggs & $\downarrow$ & $\begin{array}{l}\text { Perkin et al. } \\
\text { (2015) }\end{array}$ \\
\hline & Polyphils & Non-specialized spawners no preferred habitat & $\uparrow$ & $\begin{array}{l}\text { Breine et al. } \\
\quad(2008)\end{array}$ \\
\hline & Ariadnophilic & Adhesive eggs deposited within glued nest & $\downarrow$ & $\begin{array}{l}\text { Kruk et al. } \\
\quad(2017)\end{array}$ \\
\hline \multirow[t]{4}{*}{$\begin{array}{l}\text { Migration } \\
\text { guilds }\end{array}$} & $\begin{array}{l}\text { Short range migrations within } \\
\text { river "zones" }\end{array}$ & Freshwater migrants & $\downarrow$ & $\begin{array}{l}\text { Pont et al. } \\
\quad(2006)\end{array}$ \\
\hline & $\begin{array}{l}\text { Intermediate range migrations } \\
\text { between river "zones" but } \\
\text { within river basin }\end{array}$ & Freshwater migrants & $\downarrow$ & $\begin{array}{l}\text { Pont et al. } \\
\text { (2006) }\end{array}$ \\
\hline & $\begin{array}{l}\text { Long range anadromous } \\
\text { migrators }\end{array}$ & Migrate from the sea into the river to spawn & $\downarrow$ & $\begin{array}{l}\text { Pont et al. } \\
\text { (2006) }\end{array}$ \\
\hline & $\begin{array}{l}\text { Long range catadromous } \\
\text { migrators }\end{array}$ & Migrate out to the sea to spawn & $\downarrow$ & $\begin{array}{l}\text { Pont et al. } \\
\text { (2006) }\end{array}$ \\
\hline
\end{tabular}


Scoring of the selected metrics

The individual fish metrics selected for the index development should be assigned to numbers without a unit, called scores, which are in turn integrated into index values. There are several approaches for scoring the selected metrics (Blocksom 2003). The reference sites have a key role in scoring; reference sites with minimum disturbance can be used to determine optimal scores (Quataert et al. 2011; Mostafavi et al. 2015). If the reference conditions are not available, preclassification systems can be used (e.g., Fame manual 2004; Quataert et al. 2011).

The scoring method may have a strong impact on the performance of the developed index. Discrete scoring was first used by Karr (1981) and it is one of the most frequently applied scoring methods for multimetric biotic indices. In discrete scoring methods, categorical scores (e.g., 1, 3, 5) are attributed to a certain range of metric values. On the contrary, in continuous scoring methods, metric values are scored on a continuous scale depending on the upper and lower thresholds of the observed values. The upper and lower thresholds can be 75th and 25th or 95th and 5th percentiles, respectively (Bozzetti and Schulz 2004; Dolph et al. 2010). The scores generally range between 0 to 100 or 0 to 10 depending on the scoring approach. In general, metric values increasing with better environmental quality get higher scores. Negative metrics get lower scores with increasing environmental quality. Scoring for these metrics is done in a similar way considering that their scores increase as the metric value decreases. It should be noted that under natural conditions a population should not consist of only one type of trophic guilds such as carnivorous fish. In such cases, a threshold for such metrics can be defined and higher values are assigned to lower scores not corresponding to the best situation (Breine et al. 2015).

The effect of natural variables (i.e., altitude, slope, etc.) on metric values should be assessed using appropriate statistical tools such as correlation tests. Calibrations are necessary when there is a significant relationship between natural variables and metric values (Karr 1981; Breine et al. 2004). The metrics to be scored can be grouped into different ranges of natural variables. For example; 3 different groups can be tabulated according to the altitude ranging from 0 to $250 \mathrm{~m}, 250$ to $500 \mathrm{~m}$ and $>500 \mathrm{~m}$. Thus, the upper and lower thresholds for metric values will be different in each group which enables an adjustment for scoring according to that of natural variable. However, this necessitates a very large dataset for each group to provide reliable estimates.

\section{EQR calculation and determination of the thresholds for EQR}

The sum of the scores of the selected metrics gives the total IBI for each sampling location. To be compatible with the WFD, the IBI values are then transformed to EQR values. $E Q R$ is a numerical value ranging between 0 (bad status) and 1 (high or pristine status). EQR is calculated with the following formulae:

$$
\mathrm{EQR}=(\mathrm{IBI}-\text { lowest IBI possible }) /(\text { maximum IBI possible }- \text { lowest IBI possible }) .
$$

The EQR value 1 corresponds to the upper limit of the metric value under reference conditions. On the other hand, when no reference sites are available the highest observed value for this particular metric can be scored as 1 . If according to the preclassification no sites with a high or good quality are present, the value for score 1 can be obtained by extrapolation. EQR value 0 is defined by the lowest metric value for the sites preclassified as bad. Again extrapolation can be used if no bad sites are available.

\section{Validation}

The validity of the index can be tested by internal or external datasets (Oberdorff et al. 2002; Mostafavi et al. 2015). An independent dataset including both pristine and impacted sites from water bodies with features similar to those used to develop the index is required for the external validation. The preclassification system (based on independent physical and chemical assessments) can be used for internal validation (Mercado-Silva et al. 2002). A habitat status assignment for each sampling location based on pressure variables is needed for 
preclassification. To prevent circular reasoning, habitat status assignment and metric modeling should not be based on the same abiotic variables. In addition, abiotic parameters used for habitat status assignment should have a known effect on fish guilds. If available, a national water quality regulation scheme can be used directly or with slight modifications to preclassify the sampling locations.

A second approach to validate the index is the correlation test between habitat status assignment and IBI scores (or EQR values). The higher correlation coefficient gives the better fit for the developed index.

Graphical screening of the variation in the scores for selected metrics in different EQR classes and monitoring the responsiveness of the selected metrics with increasing environmental degradation is useful for validation. The box plots indicating metric score values should follow a logical trend in different integrity classes with improving ecological status. Metrics with a high degree of variation will create an overlap in different EQR classes and they are less effective for ecological status assessment of water bodies (van de Bund and Solimini 2007). According to the WFD, a fish-based index should clearly distinguish the high/good integrity classes from moderate-poor-bad integrity classes (EU WFD 2000). Hypothetical box plots showing the expected pattern of the score for a selected metric with improving environmental quality which presents a good separation and a metric which shows great variation (i.e., overlap) in different EQR classes are given in Fig. 2.

\section{Discussion}

The assessment of the ecological status of aquatic habitats is vital for developing management strategies and helping policy makers. Thus, environmental quality assessment tools are essential to concentrate rehabilitation and restoration efforts on locations where anthropogenic activities have adverse effects. Such tools are also crucial for countries where the financial sources are limited. National fish-based ecological evaluation tools for inland water bodies are not available yet in Turkey. It is a complicated task to develop a fish-based index for Turkish freshwaters due to the high variation in riverine and lacustrine habitat types, high endemism in fish fauna, lack of knowledge on the ecology and distribution of certain fish species (especially endemic fish) and the absence of long-term historical data sets. The major challenging issues related to develop a fish-based index for Turkish freshwaters are summarized below.

\section{Abiotic data}

The determination of physical and chemical characteristics of the aquatic environment and hydromorphological features of the catchment basin are crucial for ecological quality assessments. These parameters are

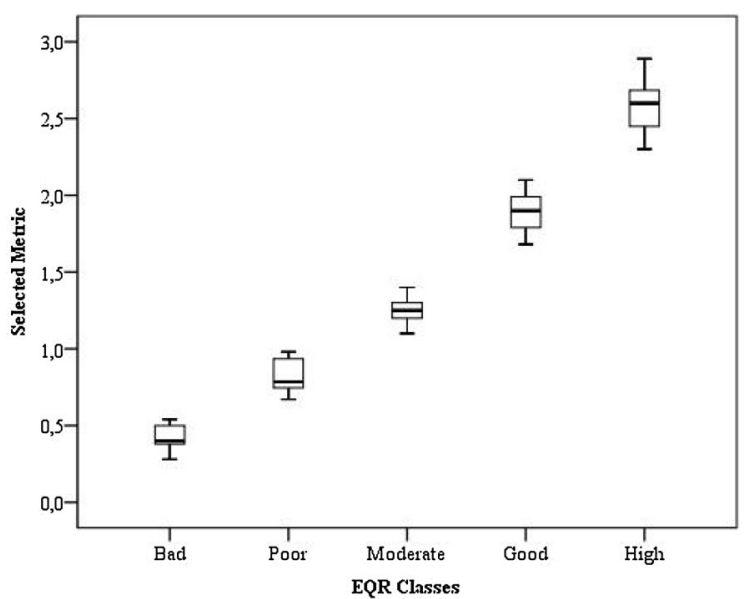

$\mathbf{a}$

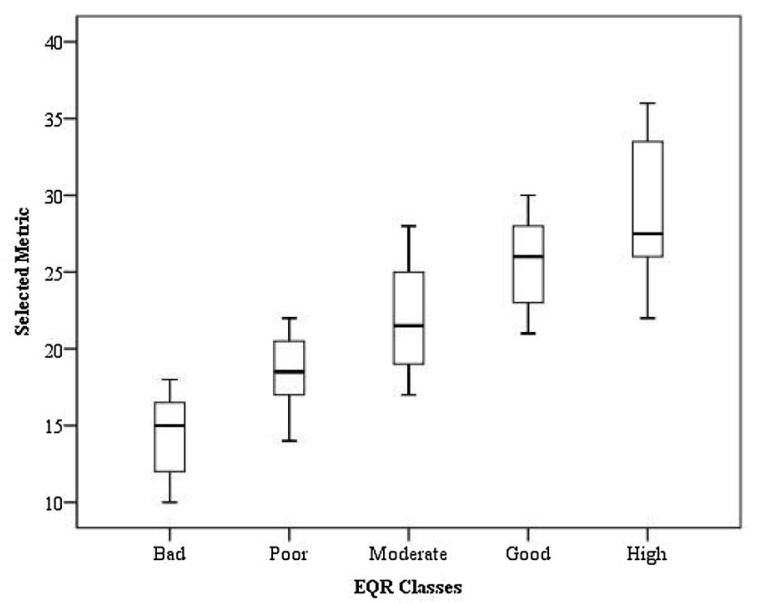

b

Fig. 2 Hypothetical box-plot diagrams showing a logical pattern of the score for a selected metric with improving quality (a) and a metric which shows great variation in different EQR classes (b) 
highly variable in freshwater ecosystems and often have an impact on the community patterns in terms of species composition, abundance, biomass (van de Bund and Solimini 2007; Hawkins et al. 2010). The reliability and power of the assessments based on the analyses of physico-chemical parameters, depend on the quality of sampling. Instant measures of the physical and chemical variables (temperature, $\mathrm{pH}$, dissolved oxygen, heavy metal concentrations, etc.) of rivers supply limited information on the immanent characteristics of those water bodies (Meybeck et al. 1996; Hunting et al. 2017). Several researchers have shown that the hydromorphological variables such as distance from the source, slope and stream order also have an effect on fish assemblages (Olaya-Marin et al. 2012; Civas et al. 2016; Wolter et al. 2016). Datasets for abiotic parameters are also useful to detect the behavior and fate of contaminants which may assist in developing management strategies. Sediment and biota are accumulative matrices for pollutants (e.g., hydrophobic and lipophilic substances); thus, they provide a less variable measurement of the pollutant load on a longer time scale (CIS 2009). The natural background concentrations have a crucial impact on the assessment of chemical status of the watersheds. The background concentrations of elements including nitrogen, phosphorus and heavy metals such as cobalt, zinc, and iron are affected by the annual runoff, atmospheric deposits, regionspecific factors (Smith et al. 2003) and particularly sediment geology and geochemistry in catchment basins (Eker and K1lıç, 2018). The assignment of the thresholds for background concentrations needs datasets from pristine or minimally impacted sites in each basin or region.

Fish data and typology

Specific indices appraising different metrics may be needed for particular fish zones or (i.e., salmonid versus cyprinid rivers) or river segments (i.e., downstream/upstream sampling locations). Thus, species composition, relative abundance and biomass of particular fish species should be tested for significant differences. Currently, there is no regional information available from Turkey and Middle East for ecoregional delineations. Abell et al. (2008) defined 14 ecoregions in Turkey by generating species list for all drainage basins in the area and combining small catchments with similar faunistic elements. However, this ecoregion delination should be validated using geographic, climatic and biological characteristics (Bailey 2005). The freshwater fish fauna in Turkey is characterized by a high degree of endemism, and a great variation among regions. Thus, adopting available fish-based indices (such as EFI) without any modification is not possible. Several riverine (source waters, head waters, lowland and highland streams, streams flowing through forests and deep valleys, mountain rivers, closed or open river basins) and lacustrine (high mountain lakes, lowland lakes, lakes with a wide range of size and depth) habitats are observed in Turkey. Thus, there is a high diversity among the hydrologic, morphologic and climatic characteristics of those water bodies. Currently, a total of 56 riverine and 23 lacustrine habitats are recognized for freshwaters in Turkey. This typology is in compliance with the WFD (System A) and solely based on altitude, slope, precipitation, flow regime, drainage area and basin geology (RBPAP 2013). However, such an abiotic typology is incapable of reflecting the differences observed in fish community structure among different sampling locations. Melcher et al. (2007) also reported a similar finding for European freshwaters. Furthermore, high number of river and lake types limits the practical applicability of this approach. Thus, there is a need for a fish-based river and lake typology development. The first step of developing fish-based typology requires an abiotic classification (based on hydrology, hydromorphology, geology, climate, etc.) which reflects the differences in fish community structure. The second step includes the biotic validation using fish data (e.g., presence/absence of certain taxa, dominant taxa, cooccurrence of species, etc.) to assure the accuracy of these classifications and to avoid any misclassifications. The wetted width, depth, flow velocity, river bed material, source type, distance to the source, channel slope, altitude, climatic characteristics (mean annual air temperature, precipitation, etc.), lake depth, shore structure and conditions, trophic status, residence time may correspond to fish species composition and abundance in rivers and lakes (Owen et al. 2001, Fame Consortium 2004). The relevant abiotic parameters and their class boundaries reflecting distinct river types or segments and lake types with homogenous fish communities can be chosen with statistical tools (e.g., cluster analysis, twinspan analysis) and expert judgement (Noble et al. 2003). To develop a fish-based typology, fish sampling sites should include all representative freshwater habitats from unimpacted or less impacted sites (i.e., calibration sites). Sampling sites where local endemism (basin-specific endemics) is high can be grouped into a higher level of discrimination (e.g., sub-zones or subtypes) (Economou et al. 2004). A high degree of classification for a fish-based typology is possible with larger 
datasets; however, generic models are better to elucidate generalizations for datasets with gaps. There are several different approaches available for establishment of a fish-based river typology for several countries including Germany (Fieseler and Wolter 2006), France (Lasne et al. 2007) and Latvia (Birzaks 2012), for large rivers such as Danube River (Eros et al. 2017), for European rivers (Melcher et al. 2007), and for lakes in Ireland (Kelly et al. 2012). However, it is still possible to combine sampling locations with different characteristics in one single index, e.g., upstream index developed in Flanders (Breine et al. 2004).

\section{Sampling}

Each method of fish sampling has its own specific selectivity on a species level or size. It is always possible to miss a species unless considerable effort is exerted (Almeida et al. 2017). Personal experience has shown that small-bodied fish such as Gambusia holbrooki generally inhabit very shallow waters along the shoreline in lakes and avoid open waters. This lowers the probability of catching such fish. We also observed that multimesh gillnets are more likely to catch smaller fish than larger fish, while smaller fish are less vulnerable to electrofishing. Similar findings were also reported by Ruetz et al. (2007). Furthermore, we also observed that multi-mesh gillnets were usually unsuccessful to catch Northern pike (Esox lucius). Missing a top-carnivorous species (i.e. northern pike) which is very common in Turkish lakes and reservoirs will affect the estimates of the index developed. Thus, the limitations of the fish sampling methods should be well understood. Data collected by different sampling methods should not be combined or mixed to reduce the bias related to any single protocol (U.S. EPA 2002). Sampling locations should represent a gradient from highly impacted to less impacted sites reflecting all river and lake types. Since the flow velocity is very high in many rivers during spring due to snow melt and rainfall, fish sampling should be carried out during late summer which corresponds to low-flow periods in Turkish rivers. Since most of the natural lakes in Turkey are under heavy impact (RBPAP 2013, SAP 2016), it is a challenging factor to obtain a series of sampling sites for lakes from pristine locations. Paleolimnological methods including analysis of sedimentary e-DNA for fish are promising techniques (Turner et al. 2015; Domaizon et al. 2017) to elucidate unimpacted conditions in lakes. There are several river segments in Turkey without a major human disturbance (calibration sites); thus, monitoring data can be used for rivers to develop a fish-based typology. The number of multi-mesh nets offered by standard methods (CEN 2003b) is not feasible for large lakes. Thus, future research focuses on the assessment of optimal fishing method in such lakes. There is also a need for an optimal fishing method for large and nonwadable rivers.

\section{Guild attribution}

The ecological guild concept was originally defined by Root (1967) as "a group of species exploiting similar environmental resources in a similar way". The guild approach has been adopted by several researchers to assess the ecological integrity in freshwaters based on the fish data (Aarts and Nienhuis 2003; Welcomme et al. 2006; Noble et al. 2007; Schmutz et al. 2007). Any gaps or limited information related to the ecological requirements of certain fish will jeopardize the attribution of fish species to particular guilds and construction of candidate metric list. Thus, such cases should be handled carefully with the available literature and expert judgement; a consensus is needed on guild attribution of fish species. Since most of the previous ichthyological research in Turkey focused on faunistic records and species composition, there is a gap on the scientific literature mainly concerning feeding ecology and tolerance of fish (particularly endemic fish) species. A few individuals can be retained for stomach content analysis to elucidate the feeding biology of such fish. Overall tolerance can be used if there are partial data on the tolerance of fish to specific disturbances. It is better to keep such gaps blank, instead of processing with doubtful or wrong information. Metrics with patchy data are likely to be rejected by the models. However, we suggest a posterior evaluation whether to omit or to keep such metrics in candidate metric list. Note that metrics including fewer species may create a bias in scoring (Breine et al. 2004; Fame Consortium 2004). Thus, evaluation of the ecological quality of such water bodies with a naturally low species richness may be based on a limited number of metrics. A similar approach was used by Cheimonopoulou et al. (2011) for small rivers in Greece and Mostafavi et al. (2015) for cyprinid rivers in Iran. 
Statistical analysis

The selection of responsive metrics can be done by several statistical methods including PCA, CCA and linear models. PCA uses variance to assess the importance of a particular dimension (pressure). High variance axes are, therefore, treated as principle components while low variance axes as noise. In a study comparing the abilities of generalized linear models (GLM) and CCA, it is stated that GLMs gave better predictions than CCA models (Guisan et al. 1999). The authors stated that GLMs provide specific predictors for each tested metric, while CCA uses same set of predictors for all tested metrics. They also noted that CCA provided more accurate results for rare or uncommon species among sampling sites. Linear mixed models are useful to demonstrate how independent variables (predictors) affect dependent variables (metrics) (Van Sickle et al. 2004). They are easy to develop and are considered reliable tools for ecological studies (Einheuser et al. 2013).

\section{Eqr}

The ecological status assessments based on EQR are useful for the assignment of a water body to a peculiar ecological status. EQR also enables comparability among different assessment methods through intercalibration and presents a standard ecological status assignment (van de Bund and Solimini 2007). This assignment has a crucial role in decision making for developing management strategies, efficient use of financial resources and diverting restoration efforts on precise spots.

The degree of deterioration of the sampling locations is important for EQR-based classifications. For a natural water body, the goal is to reach the "good ecological status (GES)". However, heavily modified water bodies (HMWB) which have substantial changes in their hydrogeomorphological characters resulting from human activities cannot reach this status. The best status an HMWB can obtain is the "maximum ecological potential" (MEP) or "Good Ecological Potential" (GEP). According to the WFD, the "MEP" is defined as the state where "the values of the relevant biological quality elements reflect, as far as possible, those associated with the closest comparable surface water body type, given the physical conditions, which result from the heavily modified characteristics of the body" (CIS 2003a, b). GEP is equivalent to achieving "Good Ecological Status" in unmodified water bodies once the impact of physical modifications necessary to support the use is taken into account. Thus, EQR for GEP or MEP is designated to 1, under which other integrity classes are defined. The thresholds for EQR classes are designated according to a particular degree of deviation from the reference conditions (van de Bund and Solimini 2007). Thus, type-specific reference conditions have a direct impact on the thresholds.

The main purpose of the use of $\mathrm{EQR}$ is to provide a comparable assessment among different methodologies. However, there is no agreement on the determination of class boundaries of EQR values yet (van de Bund and Solimini 2007). Intercalibration practices are crucial to ensure that the EQR class boundaries for high-good and good-moderate for different fish-based assessment methodologies correspond to comparable degree of habitat impairment. Thus, any misclassification due to a variety of errors, particularly related to assessment methods, should be eliminated or minimized by reliable statistical approaches.

Validation

The validation of the index is critical, however, often neglected part of the index development (Karr and Chu 1999, Mercado-Silva et al. 2002). The preclassification of the sampling sites (i.e., internal validation) is useful where the external independent datasets are not available. The preclassification of habitat status should be done on a 5 class system to be compatible with the WFD. The Turkish Surface Water Quality Directive (SWQD 2012) is based on 4 water quality classes. Thus, if the preclassification of the sampling locations will be done using this system, a slight adjustment is needed. Although, the preclassification is not an accurate system for habitat status assignment, it is accepted as a useful procedure to rank the sampling locations and develop an index (Quataert et al. 2011). The habitat assignment and EQR classification should match considering a one class divergence as acceptable errors (Type I or II error; see Breine et al. 2010). 


\section{Conclusion}

Environmental quality assessments in aquatic habitats with reliable approaches are of central importance for effective use of financial funds in developing countries. Using inaccurate methods to evaluate ecological status in water bodies result in erroneous assignments which lead to waste of time and money. Although there are several challenging factors to develop a fish-based index for Turkish freshwaters, it is still possible to develop a reliable index using appropriate statistical methods. Metric selection, scoring and validation should be based on valid approaches including responsiveness tests and redundancy analyses.

Future studies should focus on the development of a fish-based typology for Turkish freshwaters, establishment of the guild attribution of freshwater fish (particularly endemic fish) in Turkey and optimal sampling method for non-wadable rivers and large lakes. Any gaps hindering the index development should be handled carefully considering available literature and expert judgement. It is better to leave such gaps blank where a consensus cannot be reached, instead of proceeding with questionable knowledge.

Acknowledgements A part of this study was conducted in INBO (Institute of Nature and Forest, Brussels). Mehmet Borga Ergönül was awarded by the scholarship of The Scientific and Technological Research Council of Turkey (2219- Research Fellowship Programme for Post-Doctoral Studies) during his stay in INBO in Belgium.

Open Access This article is distributed under the terms of the Creative Commons Attribution 4.0 International License (http:// creativecommons.org/licenses/by/4.0/), which permits unrestricted use, distribution, and reproduction in any medium, provided you give appropriate credit to the original author(s) and the source, provide a link to the Creative Commons license, and indicate if changes were made.

\section{References}

Aarts BGW, Nienhuis PH (2003) Fish zonations and guilds as the basis for assessment of ecological integrity of large rivers. Hydrobiologia 500:157-178

Aazami J, Esmaili-Sari A, Abdoli A, Van den Sohrabi H, Brink PJ (2015) Monitoring and assessment of water health quality in the Tajan River, Iran using physicochemical, fish and macroinvertebrates indices. J Environ Health Sci Eng. https://doi.org/ 10.1186/s40201-015-0186-y

Abell R, Thieme ML, Revenga C et al (2008) Freshwater ecoregions of the world: a new map of biogeographic units for freshwater biodiversity conservation. Bioscience 58:403-414

Almeida D, Alcaraz-Hernández JD, Merciai R, Benejam L, García-Berthou E (2017) Relationship of fish indices with sampling effort and land use change in a large Mediterranean river. Sci Tot Environ 605-606:1055-1063

Anonymous (2003) Rivers and Lakes-typology, reference conditions and classification systems. Common Implementation Strategy for the Water Framework Directive Guidance Document 10

Bailey RG (2005) Identifying Ecoregion Boundaries. Environ Manag 34(Suppl. 1):14-26

Bain M, Finn J, Booke H (1988) Streamflow regulation and fish community structure. Ecology 69(2):382-392

Bellan-Santini D (1980) Relationship between populations of amphipods and pollution. Mar Pollut Bull 11:224-227

Belpaire C, Smolders R, Vanden Auweele I, Ercken D, Breine J, Van Thuyne G, Ollevier F (2000) An index of biotic integrity characterizing fish populations and the ecological quality of Flandrian waterbodies. Hydrobiologia 434:17-33

Birzaks J (2012) Occurrence, abundance and biomass of fish in rivers of Latvia in accordance with river typology. Zool Ecol 22(1):9-19

Blocksom KA (2003) A performance comparison of metric scoring methods for a multimetric index for Mid-Atlantic Highland streams. Environ Manag 31(5):670-682

Boulton AJ (1999) An overview of river health assessment: philosophies, practice, problems and prognosis. Freshw Biol 41:469-479

Bozzetti M, Schulz UH (2004) An index of biotic integrity based on fish assemblages for subtropical streams in southern Brazil. Hydrobiologia 529:133-144

Breine J, Simoens I, Goethals P, Quataert P, Ercken D, Van Liefferinghe C, Belpaire C (2004) A fish-based index of biotic integrity for upstream brooks in Flanders (Belgium). Hydrobiologia 522:133-148

Breine J, Maes J, Stevens M, Simoens I, Elliott M, Hemingway K, Van den Bergh E (2008) Habitat needs to realise conservation goals for fish in estuaries: case study of the tidal Schelde. Harbasisns INBO. R 3:46

Breine J, Quataert P, Stevens M, Ollevier F, Volckaert FAM, Van den Bergh E, Maes J (2010) A zone-specific fish-based biotic index as a management tool for the Zeeschelde estuary (Belgium). Mar Pollut Bull 60:1099-1112

Breine J, Van Thuyne G, De Bruyn L (2015) Development of a fish-based index combining data from different types of fishing gear. A case study of reservoirs in Flanders (Belgium). Belgian J Zool 145:17-39

Camargo JA (1992) New diversity index for assessing structural alterations in aquatic communities. Bull Environ Contam Toxicol 48:428-434

CEN (European Committee for Standardization), EN 14011 (2003a) Water quality. Sampling of fish with electricity, EN 14011. CEN, Brussels 
CEN (European Committee for Standardization), EN 14757 (2003b) Water quality. Guidance on the scope and selection of fish sampling methods, EN 14757. CEN, Brussels

Cheimonopoulou MT, Bobori DC, Theocharopoulos I, Lazaridou M (2011) Assessing ecological water quality with macroinvertebrates and fish: a case study from a small Mediterranean river. Environ Manag 47:279-290

CIS (Common Implementation Strategy) (2003a) Overall approach to the classification of ecological status and ecological potential. Water Framework Directive Common Implementation Strategy Working Group 2 A Ecological Status (ECOSTAT), 53, Rome

CIS (Common Implementation Strategy) (2003b) Identification and designation of heavily modified and artificial water bodies. Water Framework Directive Common Implementation Strategy Working Group, Guidance Document No. 4, Produced by Working Group 2.2-HMWB, European Communities, 118

CIS (Common Implementation Strategy) (2009) Guidance on Surface Water Chemical Monitoring under The Water Framework Directive. Water Framework Directive Common Implementation Strategy Working Group, Guidance Document No. 19. Produced by Working Group 2.2-HMWB, European Communities, 130

Civas L, Vytaustas K, Ruta B (2016) Impact of the riverbed morphology on the source of organic material and the trophic structure of fish community along the upper reaches of the Nevezis River. Lithuania. Acta Ichthyologica et Piscatoria; Szczecin 46(4):303-312

Clavel J, Poulet N, Porcher E, Blanchet S, Grenouillet G, Pavoine S, Biton A, Seon-Massin N, Argillier C, Daufresne M, Teillac Deschamps P, Julliard R (2013) A new freshwater biodiversity indicator based on fish community assemblages. PLoS ONE 8(11):e80968

Cunico AM, Allan JD, Agostinho AA (2011) Functional convergence of fish assemblages in urban streams of Brazil and the United States. Ecol Ind 11:1354-1359

Didier J (1997) Indice biotique d'integrity piscicole pour évaluer la qualité écologique des écosystèmes lotiques. Thèse de doctorat, Presses Universitaires de Namur, Namur

EU Water Framework Directive (2000) Directive of the European parliament and of the council 2000/60/EC establishing a framework for community action in the field of water policy. Official Journal of the European Communities

Dolph CL, Sheshukov AY, Chizinski CJ, Vondracek B, Wilson B (2010) The index of biological integrity and the bootstrap: can random sampling error affect stream impairment decisions? Ecol Ind 10:527-537

Domaizon I, Winegardner A, Capo E, Gauthier J, Gregory-Eaves I (2017) DNA-based methods in paleolimnology: new opportunities for investigating long-term dynamics of lacustrine biodiversity. J Paleolimnol. https://doi.org/10.1007/s10933017-9958-y

Economou AN, Zogaris S, Giakoumi S, Barbieri R, Petridis D (2004) Developing a biotic river typology and defining reference conditions in the rivers of Greece: a spatially-based approach. Fame Consortium, 35

EFI + Consortium (2009) Manual for the application of the new European fish index-EFI + . A fish-based method to assess the ecological status of European running waters in support of the Water Framework Directive

Einheuser MD, Nejadhashemi AP, Wang L, Sowa SP, Woznicki SA (2013) Linking biological integrity and watershed models to assess the impacts of historical land use and climate changes on stream health. Environ Manage 51:1147-1163

Eker ÇS, Kılıç ED (2018) Geochemistry of Çoruh River Bed Sediments in NE Turkey: implications in Weathering-Sedimentary Cycle, Provenance, and Metal Pollution. Geochem Int 56(6):579-600

U.S. EPA (2002) Methods for Evaluating Wetland Condition: Developing Metrics and Indexes of Biological Integrity. Office of Water, U.S. Environmental Protection Agency, Washington, DC. EPA-822-R-02-016. 38

Eros T, Bammer V, Gyorgy AI, Pehlivanov L, Schabuss M, Zornig H, Weiperth A, Szaloky Z (2017) Typology of a great river using fish assemblages: implications for the bioassessment of the Danube river. River Res Appl 33(1):37-49

Fame Consortium (2004) Manual for the application of the European Fish index-EFI. A fish-based method to assess the ecological status of European rivers in support of the Water Framework Directive, 81

Fausch KD, Lyons J, Karr JR, Angermeier PL (1990) Fish communities as indicators of environmental degradation. Am Fish Soc Symp 8:123-144

Fieseler C, Wolter C (2006) A fish-based typology of small temperate rivers in the northeastern lowlands of Germany. LimnolEcol Manag Inland Waters 36(1):2-16

Freyhof J (2018) Photograph life or preserved fish in the field. http://www.fredie.eu/index.php/tutorials/55/55-photograph-life-orpreserved-fish-in-the-field. Accessed 20 May 2018

Gabriels W, Lock K, De Pauw N, Goethals PLM (2010) Multimetric Macroinvertebrate Index Flanders (MMIF) for biological assessment of rivers and lakes in Flanders (Belgium). Limnologica 40:199-207

Gallardo B, Clavero M, Sánchez MI, Vilà M (2016) Global ecological impacts of invasive species in aquatic ecosystems. Glob Change Biol 22:151-163

Gernes MC, Helgen JC (2002) Indices of biological integrity (IBI) for large depressional wetlands in Minnesota. Minnesota pollution control agency. Biological Monitoring Program, Environmental Outcomes Division, Minnesota

Growns I (2004) A numerical classification of reproductive guilds of the freshwater fishes of south-eastern Australia and their application to river management. Fish Manag Ecol 121:369-377

Guisan A, Weiss SB, Weiss AD (1999) GLM versus CCA spatial modeling of plant species distribution. Plant Ecol 143(1):107-122

Hart RC (1992) Experimental studies of food and suspended sediment effects on growth and reproduction of six planktonic cladocerans. J Plankton Res 14:1425-1448

Hawkins CP, Yong C, Roper B (2010) Method of predicting reference condition biota affects the performance and interpretation of ecological indices. Freshw Biol 55:1066-1085 
Hering D, Feld CK, Moog O, Ofenböck T (2006) Cook book for the development of a multimetric index for biological condition of aquatic ecosystems: experiences from the European AQEM and STAR projects and related initiatives. Hydrobiologia 566:311-324

Hu JT, Wang HW, Lee HY (2007) Assessment of environmental conditions of Nan-Shih stream in Taiwan. Ecol Ind 7:430-441

Hughes JE, Deegan LA, Weaver MJ, Costa JE (2002) Regional application of an index of estuarine biotic integrity based on fish communities. Estuaries 25:250-263

Hugueny B, Camara S, Samoura B, Magassouba M (1996) Applying an index of biotic integrity based on fish assemblages in a West African river. Hydrobiologia 331:71-78

Hunting ER, de Jong S, Vijver MG (2017) Assessment of monitoring tools and strategies safeguarding aquatic ecosystems within the European water framework directive. CML-rapport 192. Leiden University, Institute of Environmental Sciences, Conservation Biology, Leiden

Irvine K (2004) Classifying ecological status under the European Water Framework Directive: the need for monitoring to account for natural variability. Aquatic Conserv: Mar Freshw Ecosyst 14:107-112

ISO 5667-1 (2010) Water quality- Sampling Part 1: Guidance on the design of sampling programmes and sampling techniques. International Organization for Standardization, Geneva, Switzerland

ISO 5667-3 (2012) Water quality-sampling. Part 3: Preservation and handling of water samples. International Organization for Standardization, Geneva, Switzerland

ISO 5667-6 (2014) Water quality-sampling. Part 6: Guidance on sampling of rivers and streams. International Organization for Standardization, Geneva, Switzerland

ISO 5667-4 (2016) Water quality-sampling. Part 4: Guidance on sampling from lakes, natural and man-made. International Organization for Standardization, Geneva, Switzerland

Jekel H (2005) Sustainable water management in Europe-the water framework directive. In: Vogtmann H, Dobretsov N (eds) Transboundary water resources: strategies for regional security and ecological stability. NATO Science Series (Series IV: Earth and Environmental Sciences), vol 46. Springer, Dordrecht

Joy MK, Death RG (2004) Application of the index of biotic integrity methodology to New Zealand freshwater fish communities. Environ Manag 34(3):415-428

Karr JR (1981) Assessment of biotic integrity using fish communities. Fisheries 6:21-27

Karr JR, Chu EW (1999) Restoring life in running waters: better biological monitoring. Island Press, Washington, D.C

Kelly FK, Harrison AJ, Allen M, Connor L, Rosell R (2012) Development and application of an ecological classification tool for fish in lakes in Ireland. Ecol Ind 18:608-619

Khali MA, Kochzius M (2002) Changes in trophic community structure of shore fishes at an industrial site of the Gulf of Aqaba, Red Sea. Mar Ecol Prog Ser 239:287-299

Kruk A, Ciepłucha M, Zięba G, Błońska D, Marszał L, Tybulczuk S, Tszydel M, Penczak T (2017) Disturbed fish fauna zonation as an indicator of large-scale human impact: a case study (2011-2012) of the large, lowland Warta River, Poland. J Appl Ichthyol 33:174-188

Kuru M, Yerli SV, Mangıt F, Ünlü E, Alp A (2014) Fish biodiversity in inland waters of Turkey. J Acad Doc Fish Aquacult 3:93-120

Lasne E, Bergerot B, Lek S, Laffaille P (2007) Fish zonation and indicator species for the evaluation of the ecological status of rivers: example of the Loire basin (France). River Res Appl 23(8):877-890

Lodge DM (1993) Biological invasions: lessons for ecology. Trends Ecol Evol 8:133-137

Lyons J (2012) Development and validation of two fish-based indices of biotic integrity for assessing perennial coolwater streams in Wisconsin, USA. Ecol Ind 23:402-412

Melcher A, Schmutz S, Haidvogl G (2007) Spatially based methods to assess the ecological status of European fish assemblage types. Fish Manag Ecol 14:453-463

Mercado-Silva N, Lyons JD, Maldonado GS, Medina M (2002) Validation of a fish-based index of biotic integrity for streams and rivers of central Mexico. Rev Fish Biol Fisheries 12:179-191

Meybeck M, Kuusisto E, Mäkelä A, Mälkki E (1996) Water Quality. In: Bartmen, J. and Ballance, R. (Eds) Water quality monitoring - a practical guide to the design and implementation of freshwater quality studies and monitoring programmes, Published on behalf of United Nations Environment Programme and the World Health Organization. UNEP/WHO

Moore JA, Lew AA, Cunningham JA, Kachuba M (1997) Fish communities as indicators of environmental quality in the West River Watershed. Bull-Yale For Environ Stud 100(2):178-196

Mostafavi H, Schinegger R, Melcher A, Moder K, Mielach C, Schmutz S (2015) A new fish-based multi-metric assessment index for cyprinid streams in the Iranian Caspian Sea Basin. Limnologica 51:37-52

Nakagawa S, Schielzeth H (2013) A general and simple method for obtaining $R^{2}$ from generalizes linear mixed-effects models. Methods Ecol Evol 4:133-142

Noble RAA, Cowx IG, Starkie A (2003) Fame Wp6/7 Uk/Ecoregion 18 Spatial approach—river and fish community typology, Metric selection and analysis, 64

Noble RAA, Cowx IG, Goffaux D, Kestemont P (2007) Assessing the health of European rivers using functional ecological guilds of fish communities: standardizing species classification and approaches to metric selection. Fish Manag Ecol 14:381-392

Oberdorff T, Hughes RM (1992) Modification of an index of biotic integrity based on fish assemblages to characterize rivers of the Seine Basin, France. Hydrobiologia 228(2):117-130

Oberdorff T, Pont D, Hugueny B, Porcher JP (2002) Development and validation of a fish-based index for the assessment of 'river health' in France. Freshwater Biol 47(9):1720-1734

Olaya-Marin EJ, Martínez-Capel F, Costa RMS, Alcaraz-Hernández JD (2012) Modelling native fish richness to evaluate the effects of hydromorphological changes and river restoration (Júcar River Basin, Spain). Sci Total Environ 440:95-105 
Owen R, Duncan W, Pollard P (2001) Definition and establishment of reference conditions. REFCOND discussion paper for evaluation of techniques. Scottish Environment Protection Agency, Aberdeen, Scotland. 20

Perkin JS, Gido KB, Cooper AR, Turner TF, Osborne MJ, Johnson ER, Mayes KB (2015) Fragmentation and dewatering transform Great Plains stream fish communities. Ecol Monogr 85(1):73-92

Pont D, Hugueny B, Beier U, Goffaux D, Melcher A, Noble R, Rogers C, Roset N, Schmutz S (2006) Assessing river biotic condition at a continental scale: a European approach using functional metrics and fish assemblages. J Appl Ecol 43:70-80

Pont D, Hugueny B, Rogers C (2007) Development of a fish-based index for the assessment of river health in Europe: the European Fish Index. Fish Manag Ecol 14(6):427-439

Qadir A, Malik RN (2009) Assessment of an index of biological integrity (IBI) to quantify the quality of two tributaries of river Chenab, Sialkot, Pakistan. Hydrobiologia 621:127-153

Quataert P, Verschelde P, Breine J, Verbeke G, Goetghebeur E, Ollevier F (2011) A diagnostic modelling framework to construct indices of biotic integrity: a case study of fish in the Zeeschelde estuary (Belgium). Estuar Coast Shelf Sci 94:222-233

R Development Core Team (2012) R: a language and environment for statistical computing. Vienna, Austria. http://www.Rproject.org, R: Foundation for Statistical Computing

RBPAP River Basin Protection Action Plans Project (2013) Republic of Turkey, Ministry of Forestry and Water Affairs. TUBITAK-MAM, Environment and Cleaner Production, Gebze, Kocaeli

Root RB (1967) The niche exploitation pattern of the bluegray gnatcatcher. Ecol Monogr 37:317-350

Ruetz CR, Uzarski DG, Krueger DM, Rutherford ES (2007) Sampling a littoral fish assemblage: comparison of small-mesh fyke netting and boat electrofishing. North Am J Fish Manag 3:825-831

SAP Sensitive Areas Project (2016) Determination of the sensitive areas and water quality objectives on the basis of watershed in Turkey. Republic of Turkey, Ministry of Forestry and Water Affairs. TUBITAK-MAM, Environment and Cleaner Production, Kocaeli (Turkey)

Saravanan TS, Mohamed MA, Chandrasekar R, Sundramoorthy M (2003) Freshwater fishes as indicators of Kaveri River pollution. J Environ Biol 24(4):381-389

Schinegger R, Trautwein C, Schmutz S (2013) Pressure-specific and multiple pressure response of fish assemblages in European running waters. Limnologia 43(5):348-361

Schmutz S, Cowx IG, Haidvogl G, Pont D (2007) Fish-based methods for assessing European running waters: a synthesis. Fish Manag Ecol 14:369-380

Schnier S, Cai X, Cao Y (2016) Importance of Natural and Anthropogenic environmental factors to fish communities of the Fox River in Illinois. Environ Manage 57:389-411

Schoolmaster DR Jr, Grace JB, Schweiger EW, Mitchell BR, Guntenspergen GR (2013) A causal examination of the effects of confounding factors on multimetric indices. Ecol Ind 29:411-419

Simpson EH (1949) Measurement of diversity. Nature 163:688-702

Smith RA, Alexander RB, Schwarz GE (2003) Natural background concentrations of nutrients in streams and rivers of the conterminous united states. Environ Sci Technol 37(14):3039-3047

Smolinski S, Calkiewicz J (2015) A fish-based index for assessing the ecological status of Polish transitional and coastal waters. Mar Pollut Bull 101(2):497-506

Stevens C, Council T (2008) A fish based index of biological integrity for assessing river condition in central Alberta. Technical Report, Produced by the Alberta Conservation Association, Sherwood Park and Lethbridge, Alberta, Canada, 29

Stirne J, Avcin AJ, Kerzan I, Marcotte BM, Meith-Avcin N, Vriser B, Vukovic S (1971) Selected biological methods for assessment of pollution. In: Pearson EAW, Defraja E (eds) Marine pollution and waste disposal. Pergamon Press, Oxford, pp 307-328

Sundermann A, Gerhardt M, Kappes H, Haase P (2013) Stressor prioritization in riverine ecosystems: which environmental factors shape benthic invertebrate assemblage metrics? Ecol Ind 27:83-96

Tableau A, Drouineau H, Delpech C, Pierre M, Lobry J, Le Pape O, Breine J, Lepage M (2013) A fish-based index of estuarine ecological quality incorporating information from both scientific fish survey and experts knowledge. Ecol Ind 32:147-156

ter Braak CJF, Verdonschot PFM (1995) Canonical correspondence analysis and related multivariate methods in aquatic ecology. Aquat Sci 57(3):255-289

Turner CR, Uy KL, Everhart R (2015) Fish environmental DNA is more concentrated in aquatic sediments than surface water. Biol Cons 183:93-102

van de Bund W, Solimini AG (2007) Ecological Quality Ratios for Ecological Quality Assessment in Inland and Marine Waters. REBECCA Deliverable 10. European Commission, Directorate-General Joint Research Centre, Institute for Environment and Sustainability. Office for Official Publications of the European Communities, Luxembourg

Van Sickle J, Baker J, Herlihy A, Bayley P, Gregory S, Haggerty P, Ashkenas L, Li J (2004) Projecting the biological condition of streams under alternative scenarios of human land use. Ecol Appl 14:368-380

Wang L, Robertson DM, Garrison PJ (2007) Linkages between nutrients and assemblages of macroinvertebrates and fish in wadable streams: implication to nutrient criteria development. Environ Manag 39:194-212

Welcomme RL, Winemiller KO, Cowx IG (2006) Fish environmental guilds as a tool for assessment of ecological condition of rivers. Rivers Res Appl 22:377-396

Whitfield AK, Elliott M (2002) Fishes as indicators of environmental and ecological changes within estuaries: a review of progress and some suggestions for the future. J Fish Biol 61:229-250

Wolter C, Buijse AD, Parasiewicz P (2016) Temporal and spatial patterns of fish response to hydromorphological processes. River Res Appl 32:190-201

Wu W, Xu Z, Yin X, Zuo D (2014) Assessment of ecosystem health based on fish assemblages in the Wei River basin, China. Environ Monit Assess 186:3701-3716 
Yerli SV, Kormaz M, Mangit F (2016) Biological assessment by a fish-based index of biotic integrity for Turkish inland waters. In: Taylor WW, Bartley DM, Goddard CI., Leonard NJ, Welcomme R (Eds). Freshwater, fish and the future: Proceedings of the Global cross-sectoral conference. Food and Agriculture Organization of the United Nations, Rome; Michigan State University, East Lansing; and American Fisheries Society, Bethesda, Maryland, pp 91-97

\section{Publisher's Note}

Springer Nature remains neutral with regard to jurisdictional claims in published maps and institutional affiliations. 